\title{
Community structure analysis of soil insects and their potential role as bioindicators in various ecosystem types in Lombok, West Nusa Tenggara, Indonesia
}

\author{
IMMY SUCI ROHYANI \\ Program of Biology, Faculty of Mathematics and Natural Sciences, Universitas Mataram. Jl. Majapahit No. 62, Mataram 83125, West Nusa Tenggara, \\ Indonesia. Tel./fax.: +62-370-646506, email: immysuci@ yahoo.co.id
}

Manuscript received: 16 December 2019. Revision accepted: 22 August 2020

\begin{abstract}
Rohyani IS. 2020. Community structure analysis of soil insects and their potential role as bioindicators in various ecosystem types in Lombok, West Nusa Tenggara, Indonesia. Biodiversitas 21: 4221-4227. Various types of ecosystems can be found in Lombok, with the dominant ecosystems are natural forest, mangrove, mixed garden, rice field, and mining. These ecosystems have a high level of biodiversity and unique flora and fauna communities, including soil insects that partake in the process of ecosystem energy flow. This study aimed to analyze the community structure of soil insects and their potential role as bioindicators in five types of dominant and unique ecosystems in Lombok island. The data collection was done using pitfall traps, yellow pan traps, baited pitfall traps, soil sampling, and litter collection. The findings revealed that there are 60,439 individuals, 79 families, and 16 orders of insects in various types of ecosystems. Diversity $\left(\mathrm{H}^{\prime}\right)$ and evenness $(\mathrm{E})$ index values for family level in all ecosystem types are low on average $\left(\mathrm{H}^{\prime}=0.76\right.$ and $\mathrm{E}=0.10$ ). Cerambycidae (Coleoptera), Trichogrammatidae (Hymenoptera), and Cicindelidae (Coleoptera) are a potential bioindicator in the forest, in the mangrove, and in the rice field ecosystems, respectively. However, the potential bioindicator could not be found since the distribution of the family is almost even in the garden ecosystem. The Tenebrionidae (Coleoptera) and the Acroceridae (Diptera) are soil insects with relatively high abundance and are found only in the mining ecosystems.
\end{abstract}

Keywords: Bioindicators, community structure, ecosystem types, Lombok, soil insects

\section{INTRODUCTION}

Ecosystems consist of all organisms living in a community, as well as all abiotic factors that interact with these organisms. The most crucial condition for an ecosystem is the flow of energy (food chain) and the material cycle that occurs in it. Based on its biogeographic attributes, Lombok island belongs to one of the seven unique ecosystem types in Indonesia. Moreover, in terms of its zoogeographical and ecological aspects, the island possesses a unique and essential characteristic value since it is within the Wallace crossed-line ecological transition between the continents of Asia and Australia.

There are various types of ecosystems in Lombok, with the dominant ecosystem are natural forest, mangrove forest, mixed garden, rice field, and mining. In these ecosystems, there are unique flora and fauna communities with high biodiversity, including soil insects. Soil insects refer to soil fauna living partially or entirely spent in the soil. Insects utilize soil as their home, their food hunting area, and their defense. According to Rohyani (2001), soil insects play a role in the overhaul of organic materials, parasites, and predators in soil ecosystems. Soil insects possess even distribution at the trophic level, which grants them a role in maintaining ecosystem balance (Kinasih et al. 2017).

Insects have a large number of species and individuals at about $64 \%$ (950,000 species) of the overall estimated numbers of flora and fauna species on earth (Shahabuddin
2003). Such an abundant number allows soil insects to be employed as bio-indicators of environmental quality. According to Kovacs (1992), the criteria selecting a species to be used as a biological indicator are the sufficient number of abundance and a specific reaction to changes in its environment. Thus, the use of soil insects as bioindicators has its advantages, for it is more costeffective, and it is also depicting higher environmental conditions compare to vertebrate and plant groups (Bisevac and Majer 1998). The use of insects as bioindicators of ecosystems and environmental quality has been carried out in many countries, wherein the taxa used as the bioindicators involves the orders of Orthoptera, Odonata, and Lepidoptera. Lepidoptera was used to monitor the accumulation of heavy metals in industrial areas in Pakistan (Azam et al. 2015); Coleoptera was applied to monitor the health level of forest ecosystems in Canada (Pearce and Venier 2006); Orthoptera (grasshopper) was to monitor habitat quality in Southern Africa (Samways and Bazelet 2011); termite groups or Isoptera to monitor functional processes in tropical forests (Jones and Eggleton 2000); and Collembolla was used as an indicator of soil fertility and revegetation success in Indonesia (Suhardjono 1985: Nurtjahya et al. 2007; Rohyani et al. 2013).

Research related to the diversity of soil insects on Lombok Island has been conducted in several locations, namely Endok beach with a low diversity of insects (Ilhamdi 2016), and Sesaot private forest with a moderate level of diversity (Nasir 2013). Research regarding the 
analysis of community structures and the potential of soil insects as bioindicators in various types of ecosystems on Lombok Island has never been done. Information about community structure consisting of abundance, diversity, evenness, and dominance of species, as well as their bioindicator potential is very important in providing an overview of the ecological conditions of various types of ecosystems, as a reference in management for sustainable ecosystem development.

\section{MATERIALS AND METHODS}

\section{Study area}

This research was conducted in several types ecosystems found in Lombok Island, West Nusa Tenggara Province, Indonesia, namely natural forest ecosystem (Mount Rinjani National Park area, Jeruk Manis Village, East Lombok), mangrove forest ecosystem (Tawun Sekotong, West Lombok), mixed garden ecosystem (Sesaot, West Lombok) and rice field ecosystem (Labuapi, West Lombok), and mining ecosystem (Pelangan, West Lombok).

\section{Procedures}

The sample points were decided by using a purposive sampling method. The sampling of soil insects was carried out in March until May 2018, by making a 100 m main transects line at each research location. For every $10 \mathrm{~m}$ of the main transect line, a $5 \mathrm{~m}$ additional perpendicular (horizontal) transect line was added to the right and left. At each point of main and additional transects, five traps for soil insects were installed randomly (Rohyani and Ahyadi 2017).

The methods applied to collect the soil insects were pitfall trap, pitfall trap with chicken meat bait, yellow pan trap, soil sampling, and litter collection. The collected soil and litter were then stored using a calico sack to be extracted in a modified barrel funnel for seven days. For every collection method, ten traps were installed for three days at each research location.

Identification of soil insects was carried out at the morphospecies stage by matching the characteristics of the soil insects obtained with the identification keys by Borror et al. (1996), Bugguide (2012), Suin (2006), and Lilies (1992). The identification was carried out up to the family level in the laboratory of Mathematics and Natural Sciences, Mataram University, Indonesia.

\section{Data analysis}

Data analysis conducted was relative abundance (RA) (Magurran 1987). Relative abundance of a species means the abundance of a species divided by the total abundance of all species in a community. The diversity of soil insects is calculated based on the Shannon Wiener diversity index $\left(\mathrm{H}^{\prime}\right)$, and the evenness of species is calculated by the Evenness Shannon Wiener index (E) (Krebs 1999). The index equation is as follows:

$$
\begin{aligned}
& \mathrm{RA}=\frac{n_{i}}{N} x 100 \% \\
& \mathrm{H}^{\prime}=-\sum\left[\frac{n_{i}}{N} \ln \frac{n_{i}}{N}\right] \\
& \mathrm{E}=\frac{H r}{\ln S} \\
& \mathrm{D}=\sum_{1=1}^{S}\left[\frac{n_{i}}{N}\right]^{2}
\end{aligned}
$$

Where:

$\mathrm{ni}=$ the number of individual in the family to $\mathrm{i}$

$\mathrm{N}=$ the total number of individuals in all types of family

$\mathrm{S}=$ the number of family types

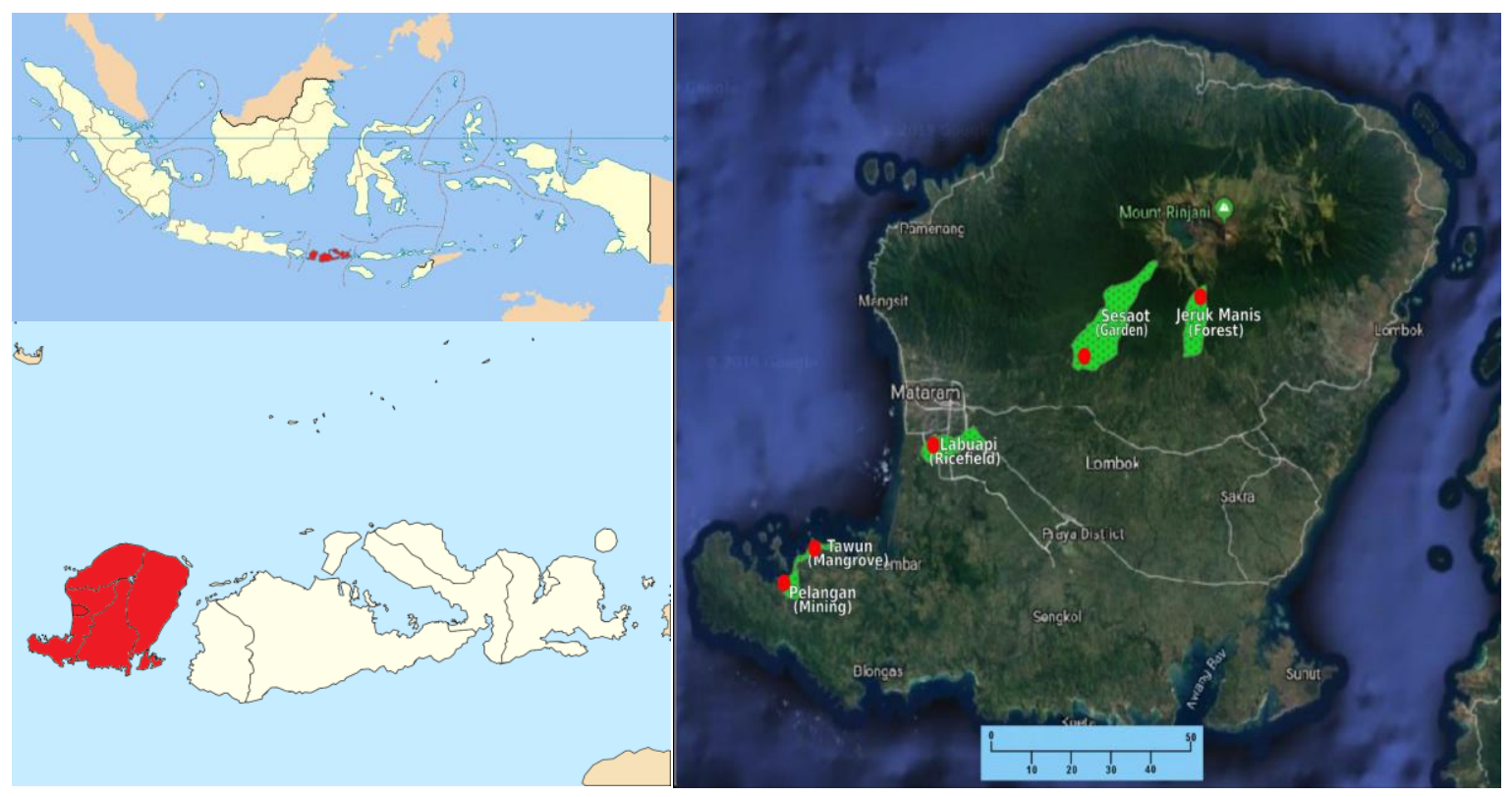

Figure 1. Study site in Lombok Island, West Nusa Tenggara Province, Indonesia (source: Google map) 
According to Fachrul (2007), diversity index, evenness index, and domination index were classified as follows:

Diversity index:

High diversity: $H^{\prime}>3$

Moderate diversity: $1<H^{\prime}<3$

Low diversity: $H^{\prime}<1$

Evenness index:

Low family evennes: $\mathrm{E}=0$

Family distribution is relatively uniform: $\mathrm{E}=1$

Domination index:

No species is dominant: $\mathrm{D}=0$

Dominant species exists: $\mathrm{D}=1$

\section{RESULTS AND DISCUSSION}

\section{Community structure of soil insects in various types of ecosystem in Lombok Island}

In this study, the total number of soil insect individuals in several types of ecosystems in Lombok island amounted to 60,439 individuals (Table 1 ). This number is sufficiently high because the research was carried out on a variety of complex ecosystem types, with different types of vegetation and litter thickness as well as diverse environmental conditions. This research also applied five methods of collecting soil insects to make it possible to obtain a very large number of soil insects.

The highest number of individuals amounting to 39,441 was collected in the mixed garden ecosystem (Table 1). The high number of insect individuals found in mixed garden ecosystems is allegedly related to the diversity of vegetation, which is a source of litter in the ecosystem. Litter is the most preferred place by many taxa of soil insects. According to Rohyani et al. (2013), thick litter can create a microclimate suitable for the habitat of soil fauna. Litter at the surface of the soil is a food source for various organisms, especially the ones that play a role in degrading litter.

The lowest number of soil insect individuals was found in the mangrove forest ecosystem, amounting to 486 individuals (Table 1). Overall, the low number of soil insect individuals obtained is thought to be related to the high levels of salinity in the ecosystem, which thus caused only certain types of soil insects found in the ecosystem.

The total of orders and families of soil insects collected in all dominant types of ecosystems in Lombok island amounted to 16 orders and 79 families (Table 1). The polyculture rice field ecosystem (14 orders) has the highest number of orders among the observed ecosystems. In contrast, the highest numbers of families are found in mixed garden ecosystem (46 families) and natural forest ecosystem (45 families). In the Manggis Gadungan Nature Reserve Park and Mangli coffee plantation area in Kediri Regency, nine orders and 21 families of soil insects were found (Permana 2016). Meanwhile, Basna et al. (2017) discovered ten orders and 23 families of soil insects in the Tumpa Mountain Great Forest Park.

The abundance of orders and families of soil insects obtained in this study was higher compared to the other studies due to the variety of ecosystems in the study sites. The number of soil insects found during the investigations is related to the variety of sampling methods performed during the research. In natural forests, Nuraeni and Mangesu (2017) obtained eight orders and eleven families of soil insects by performing two sampling methods. Implementing the same methods, they found five orders and seven families in plantation forests. Though, these results are lower than those of Rohyani and Ahyadi research (2007), which performed five methods and located nine orders and 42 families of soil insects. The litter collection method produces the highest representation of soil insect orders, while the trap method provides the highest yield in collecting the number of soil insect families. According to Byers (1992) and Schowalter (2006), the color and shape of the trap can affect the number of insects captured. The diversity of the soil arthropod population is also strongly influenced by the trap method used (Subahar 2000).

The diversity index $\left(\mathrm{H}^{\prime}\right)$ and the evenness index $(\mathrm{E})$ for the overall family level in all ecosystem types are low on average $\left(H^{\prime}=0.76\right.$ and $\left.E=0.10\right)$ (Fachrul 2007). The low average values of the diversity and evenness index show that the overall ecosystems under study were not stable because they had low complexity and productivity, as well as a low interaction between families. This condition shows that the families found in all of these ecosystems almost had the same ecological niche.

Table 1. Community structure of soil insect in various types of ecosystems in Lombok Island, West Nusa Tenggara Province, Indonesia

\begin{tabular}{|c|c|c|c|c|c|c|}
\hline Parameters & Forest & Mangrove & Garden & Ricefield & Mining & Total \\
\hline Number of individuals (N) & 13638 & 486 & 39441 & 5148 & 1726 & 60439 \\
\hline $\operatorname{Order}(\mathrm{O})$ & 9 & 10 & 13 & 14 & 13 & 16 \\
\hline Family (F) & 45 & 31 & 46 & 35 & 38 & 79 \\
\hline Diversity index $\left(\mathrm{H}^{\prime}\right)$ & 0.86 & 1.44 & 0.18 & 0.47 & 0.86 & 0.76 \\
\hline Evenness index (E) & 0.09 & 0.23 & 0.02 & 0.05 & 0.12 & 0.10 \\
\hline Dominance (D) & 1.47 & 5.20 & 1.07 & 1.44 & 1.23 & 2.08 \\
\hline
\end{tabular}


The low average value of the evenness index indicates that the distribution of the abundance of soil insects in each family was uneven. The low evenness index value was related to the high average of the domination index of more than one (Fachrul 2007). This condition depicts the existence of a family that dominated other families so that the community structure became unstable due to the ecological stress. Formicidae family was a dominant family of soil insects found in almost all types of ecosystems (Table 2). According to Odum (1993) and Campbell (2004), the domination of one population provokes the reduction of other populations. Such reduction also affects the diversity of the community.

Compare to the other ecosystem, the mangrove forest ecosystem found to had the highest diversity index $\left(\mathrm{H}^{\prime}\right)$ and evenness $(\mathrm{E})$ index $\left(\mathrm{H}^{\prime}=1.44\right.$ and $\left.\mathrm{E}=0.23\right)$. The high total value of this index is closely related to the high dominance value in the ecosystem, which is 5.20 (Fachrul 2007). The high value of the domination index indicates that the mangrove forest ecosystem had uneven distribution. It also related to the existence of ecological pressure, which made the composition of the population unstable. This condition is assumed to be affected by environmental factors, namely salinity, which limited the existence of insect populations in mangrove forest ecosystems. According to Adianto (1993), life in the soil is influenced by salinity, which determines the presence of certain soil insects. In the mangrove forest ecosystem, there are five dominating families, namely Gryllidae, Formicidae, Hydrophilidae, Isotomidae, and Entomobridae. The dominant soil insects found in the mangrove forest ecosystem had the same adaptability and survival ability in that ecosystem.

Tabel 2. Relative Abundance (RA) of soil surface insects in various ecosystem types

\begin{tabular}{|c|c|c|c|c|c|}
\hline \multirow[b]{2}{*}{ Taxa } & \multicolumn{5}{|c|}{ Ecosystem types } \\
\hline & Forest & Mangrove & Garden & $\begin{array}{l}\text { Rice } \\
\text { field }\end{array}$ & Mining \\
\hline \multicolumn{6}{|l|}{$\overline{\text { Blattodea }}$} \\
\hline Blattidae & 0.02 & - & 0.02 & 0.47 & 0.23 \\
\hline \multicolumn{6}{|l|}{ Collembola } \\
\hline Chelonethy & - & - & - & 0.02 & - \\
\hline Entomobridae & 1.07 & 1.72 & 0.41 & 2.83 & 1.21 \\
\hline Hypogasturidae & 0.21 & - & 0.32 & 0.19 & 0.11 \\
\hline Isotomidae & 3.34 & 6.37 & 0.32 & 3.8 & 6.55 \\
\hline Neanuridae & 0.07 & - & - & 0.11 & - \\
\hline Onychioridae & - & 0.17 & 0.01 & - & - \\
\hline Poduromorpha & - & - & - & 0.02 & - \\
\hline Pseudachorutinae & 0.08 & 0.34 & 0.07 & 0.02 & - \\
\hline Symphypleona & 0.04 & 1.2 & 0 & 0.11 & 0.06 \\
\hline \multicolumn{6}{|l|}{ Coleoptera } \\
\hline Anthicidae & 0.01 & - & - & - & - \\
\hline Bostricidae & - & - & 0.03 & - & 0.86 \\
\hline Buprestinae & 0.01 & - & - & - & - \\
\hline Carabidae & 0.01 & - & 0.02 & 0.06 & 0.11 \\
\hline Cerambycidae & 0.51 & - & - & - & - \\
\hline Cicindelidae & - & - & - & 0.59 & - \\
\hline Cleridae & 0.04 & 0.52 & 0.34 & - & 0.06 \\
\hline
\end{tabular}

Coelometopinae

Crysomelidae

Cucujidae

Curculionidae

Elatiridae

Erotylidae

Gyrinidae

Halticidae

Hydrophilidae

Lycidae

Nabidae

Neanuridae

Nitidulidae

Passalidae

Ptiliidae

Scarabeidae

Silphidae

Staphylinidae

Stenebrionidae

Tenebrionidae

Dermaptera

Carcinophoridae

Diptera

Acroceridae

Agromyzidae

Asilidae

Cecidomyiidae

Chironomidae

Chloropidae

Dolichopodidae

Drosophillidae

Mycetophilidae

Phoridae

Psychodidae

Rhagionidae

Scatopsidae

Sciaridae

Sphoeroceridae

Tachinidae

Tipulidae

Diplura

Hemiptera

Aphididae

Homoptera

Cicadidae

Hymenoptera

Apidae

Braconidae

Formicidae

Ichneumonidae

Mymaridae

Tenthredinidae

Trichogrammatidae

Isopoda

Isoptera

Rhinotermitidae

Termitidae

Odonata

Orthoptera

Acrididae

Gryllidae

Phasmatidae

Tettigoniidae

Oligochaeta

Plecoptera

Thysanopter
0.01

0.04

$\begin{array}{ll}0.25 & 0.57\end{array}$

$\begin{array}{ll}- & 0.17 \\ 0.08 & 0.63\end{array}$

$\begin{array}{lll}- & 0.08 & 0.63\end{array}$

0.01

0.01

- 0.11

0.01

4.43

0.02

0.01

0.03

-
3.07

1.32

0.01

0.01

5.16

$\begin{array}{lll}0.38 & 0.11 & 2.01\end{array}$

$\begin{array}{lll}- & - & - \\ - & - & -\end{array}$

$\begin{array}{lll}- & 0.02 & - \\ - & 0.08\end{array}$

$\begin{array}{llll}0.01 \quad- & -\end{array}$

$\begin{array}{lll}- & 0.11 & 0.23\end{array}$

$\begin{array}{lll}0.1 & 0.19 & 0.92\end{array}$

$\begin{array}{ccc}0.01 & - & - \\ 0.01 & 0.04 & 0.11\end{array}$

$\begin{array}{lll}- & - & 0.17\end{array}$

0.34

$\begin{array}{lll}0.19 & 0.21 & 0.06\end{array}$

$\begin{array}{cc}- & - \\ 0.27 & 0.17\end{array}$

0.09

0.17

-

$\begin{array}{lll}0 & 0.04 & 0.06\end{array}$

0.03

0.01

0.17

0.0

$\begin{array}{lll}0.01 & - & 0.11\end{array}$

$\begin{array}{lll}0 & 0.02 & 0.17\end{array}$

$\begin{array}{lllll}0.88 & 0.52 & 0.48 & 0.06 & 0.86\end{array}$

$0.34-1.38$

$\begin{array}{lll}0.03 & 0.04 & 0.52\end{array}$

$\begin{array}{ll}0.34 & 1.38 \\ - & 1.03\end{array}$

0.01

-

0.09

0.04

0.01

0.33

-

0.02

0.01

0.01

0.09

0.52

(0.02

$\begin{array}{lll}0.02 & 0.09 & 0.11\end{array}$

0.04

1.09

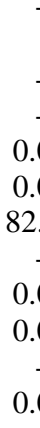

0.69

0.01

0.17

0.04

82.31

29.43

0

0.01

0.01

0.07

0.17

0.52

$\begin{array}{lll}0.08 & 0.08 & 2.18\end{array}$

0.34

$0.02 \quad 0.02$

0.02

$0.02 \quad 0.06$

0.02

0.42

0.13

0.01

.

$0.01 \quad-\quad 0.29$

$\begin{array}{llll}31.33 & 0.09 & 0.78 & 2.47\end{array}$

$\begin{array}{ll}- & - \\ 0.34 & 0.01\end{array}$

0.08

$\begin{array}{cccc}- & - & 0.02 & 0.06 \\ - & - & 0.02 & - \\ 0.17 & 0.31 & 1.18 & 0.06\end{array}$




\section{Relative abundance of soil insects in various types of ecosystems in Lombok Island}

Formicidae (Hymenoptera) is the highest relative abundance family found in the mixed garden, which is also in line with the study of Rohyani (2001). This condition occurred due to the similarity of ecosystem types and vegetation found in each research site. On the floor/surface of the mixed garden ecosystem, there are thick litters served as a food source, and as the most preferred place by Formicidae. The abundance of food sources that are able to support the development of Formicidae and the appropriate environmental conditions in each type of ecosystem became some of the factors of the high relative abundance of this family. Metabolic insect metamorphosis (complete metamorphosis) is another supporting factor for the abundance of the Formicidae due to differences in food at each stage (larva and imago), causing the family to escape from competition/struggle for food in their intra-species (Liu et al. 2013).

Formicidae is also found in almost all ecosystem types and all applied collection methods of soil insects. This family can reach up to $70 \%$ of the existing soil surface insect population (Suin 2006), which is linear with the research finding by Borror et al. (2005). Formicidae also has a large number of tribes and does its activities on the soil surface, so it was more easily found than the other families. The large number of Formicidae is affected by their habitual lifestyle, keeping themselves in colonies and consisting of castes. Kramadibrata (1995) stated that living in a colony increases the chances of individuals in the group to survive. According to Latumahina et al. (2014), Formicidae has a unique role in their interaction with plants or other insects and also has an important role in terrestrial ecosystems as predators, scavenger, herbivore, detritivore, and granivore. This condition turns Formicidae into the most dominant terrestrial group of animals in the tropics.

Entomobridae (Collembola) and Isotomidae (Collembola) were found in almost all types of ecosystems with a high abundance percentage. Both of these families are revealed to have a cosmopolitan distribution with high reproductive rates, so they tend to dominate. Their preferred habitats are litter, soil, and bushes. Collembola can live in a variety of habitats from the edge of the sea to the high snowy mountains (Suhardjono et al. 2012).

The Entomobridae (Collembola), with its slender shape (slender springtail), is known to behave as eaters of fungus, lichen, and bacteria, and also as certain plant pollen and as organic litter decomposers (Anonymous 2007; Hadley 2007). This family acts as an effective decomposer and helps a lot of nutrient cycles in the soil so that it can describe the status of land productivity in a habitat (Kanal 2004; Hadley 2007). The Isotomidae is a Collembola group that functions as a remodel of organic materials in the soil. According to Suhardjono et al. (2012), distribution areas of Isotomidae in Indonesia are mostly on the islands of Sulawesi, Sumatra, Bali, Lombok, Ternate, and Papua.

Hydrophilidae (Coleoptera) has a high percentage of abundance in the ecosystems of natural forest, mangrove forest, and mining allegedly because these ecosystems have high humidity levels since their locations are close to water sources. The natural forest ecosystem has waterfalls, mangrove forest ecosystem is strongly affected by the tide of seawater, while the mining ecosystem is adjacent to the river used as a place for waste disposal leading to the estuary. Such environmental conditions support the existence of this family, which is usually found in waters and the surrounding areas.

\section{The potential of soil insects as bioindicators of ecosystem types in Lombok island}

Based on their relative abundance percentage, some soil insects have the potential as bioindicators of the quality of their ecosystems. A bioindicator is the utilization of an organism either as part of an individual or group of organisms in order to obtain information on all or part of an environmental condition (Hornby and Batema 1997).

The potential of soil insects as bioindicators is based on high relative abundance, and the presence of these insects are only found in the observed ecosystem. According to Notohadiprawiro (1999), the composition of soil insects in a habitat or ecosystem can be the best indicator to reveal habitat quality of ecosystems. Maftu'ah et al. (2002) also reported the presence of various structural variables and composition of soil macrofauna that have the potential as bioindicators of soil health, including the abundance of termites, ants, millipedes, and earthworm biomass.

Several soil insect families were found in almost all types of ecosystems that were observed using several methods of soil insect collection (Table 2). These families include Entomobridae (Collembola), Isotomidae (Collembola), Symphypleona (Collective), Hydrophilidae (Coleoptera), Scarabaeidae (Coleoptera), Cecidomyiidae (Diptera), Drosophilidae (Diptera)), Formicidae (Hymenoptera), Gryllidae (Orthoptera). Most of these families are known to have a very large distribution and have a high abundance of both their quantity and level of diversity. Some of these families are dominant families in soil habitats, and they also like soil surface habitats that contain lots of litter serving as their shelter and food hunting areas.

Cerambycidae (Coleoptera) is a family of soil insects that are potential to be the indicators of forest ecosystem quality. This family is only found in forest ecosystems and has a high relative abundance there (Table 2). Cerambycidae or long antenna beetles play an important role in the process of decomposition and nutrient cycles for the balance of forest ecosystems (Nieto and Alexander 2010). According to Ohsawa (2010), Noerdjito (2011), and Lachat et al. (2012), Cerambycidae can be used as an indicator of a forest area because their lives are very dependent on plants. Some of these beetle species act as pollinators (Gutowski 1990; Hawkeswood and Turner 2007).

In the mangrove forest, the ecosystem of the Trichogrammatidae (Hymenoptera) is a potential bioindicator for the ecosystem quality there. This family is also known as egg parasitoids parasitizing the eggs of some rice and sugar cane pests. In the garden ecosystem, no potential bioindicator was found as the distribution of the family is almost even. Some families such as Lygaeidae 
(Hemiptera), Scatopsidae (Diptera), Culicidae (Diptera), Acylidae (Diptera), Gyrinidae (Coleoptera), Erotylidae (Coleoptera) and Dytiscidae (Coleoptera) are only found in the observed garden ecosystems, but their existence is thought to be only migrants trapped in a collection bottle, due to the very small number of families found.

In the rice field ecosystem, the family potential for being the bioindicator is the Cicindelidae (Coleoptera) family as their abundance is high, and they are only found in rice fields ecosystem. This insect family, which serves as predators that prey on various types of small insects, is commonly found in open areas and exposed to plenty of sunlight. According to Jones and Eegleton (2000) families of Scarabidae, Cicindeliadae, and Carabidae of the Coleoptera order as well as several Hymenoptera, Lepidoptera, and Isoptera orders are often used as bioindicators of forest condition.

Tenebrionidae (Coleoptera) and Acroceridae (Diptera) are families with the high relative abundance of soil insects and are found only in mining ecosystems, making them very potential as bioindicators. This type of soil insect family is usually found on leaves and under the bark. Their presence in ecosystems serves as herbivores.

In conclusion, as a whole, the structure of soil insects community in the observed ecosystems has a relatively low diversity and evenness, due to the dominance of certain soil insects. Some soil insects have a potential role as bioindicators in natural forest ecosystems, mangrove forests, rice fields, and mining areas, namely Cerambycidae (Coleoptera), Trichogrammatidae (Hymenoptera), Cicindelidae (Coleoptera), Tenebrionidae (Coleoptera) and Acroceridae (Diptera). In the garden ecosystem, there was no soil insect found as a potential bioindicator.

\section{ACKNOWLEDGEMENTS}

Further thanks to all those who have granted permission to take samples during the study, especially the Head of the Gunung Rinjani National Park Hall and all those who helped during the research process, the biology study team of the University of Mataram.

\section{REFERENCES}

Adianto. 1993. Manure, plant organic fertilizer and insecticide. Agricultural Biology. Bandung Alumni Publisher. [Indonesian]

Anonymous. 2007. The Order Collembola. http://www. earthlife.et /insects/Collembo. [20 April 2018]

Azam I, Afsheen S, Zia A, Javed, M, Saeed R, Sarwar MK, Munir B. 2005. Evaluating insects as bioindicators of heavy metal contamination and accumulation near industrial area of Gujrat, Pakistan. BioMed Res Int. DOI: 10.1155/2015/942751.

Basna M, Koneri R, Papu A. 2017. Distribution and diversity of soil insects in the Gunung Tumpa mountain forest park in North Sulawesi. J Math Nat Sci Unsrat 6: 36-42. [Indonesian]

Bisevac L, Majer JD. 1998. Invertebrates as success indicators for mine site rehabilitation. In: Asher CJ, Bell LC (eds) Proceedings of Workshop on Indicators of Ecosystem Rehabilitation Succes.

Borror DJ, Triplehorn CA, Johnson NF. 1996. An introduction to the study of insects. $6^{\text {th }}$ ed. Saunders College Publishing, Orlando.
Bugguide. 2012. Identification, images, and information for insects, spiders and their kin for the United States and Canada. http://www.bugguide.net. [19 October 2017].

Byers JA. 1992. Attraction of bark beetles, Tomicus piniperda, Hylurgops palliatus, and Trypodendron domesticum and other insect to shortchain alcohols and monoterpenes. J Chem Ecol 18 (12): 2385-2402.

Campbell NA, Jane BR, Lawrence GM. 2004. Biology. Erlangga, Jakarta. [Indonesian]

Fachrul MF. 2007. Bioecological sampling method. Bumi Aksara, Jakarta. [Indonesian]

Gutowski JM. 1990. Pollination of the orchid Dactylorhiza fuchsia by longhorn beetles in primeval forests of Northeastern Poland. Biol Conserv 51 (4): 287-297.

Hadley D. 2007. Order Collembola. http://www. insect.about.com/od/springtails. [02 March 2015].

Hawkeswood TJ, Turner JR. 2007. Record of pollination of Lomatia silaifolia (Sm.) R.Br. (Proteaceae) by the longicorn beetle Uracanthus triangularis (Hope, 1833) (Coleoptera: Cerambycidae). Calodema Suppl Paper 53:1-3.

Hornby D, Bateman GL. 1996. Potential use of plant root pathogens as bioindicators of soil health. In: Pankhurst CE, Doube BM, Gupta VVSR. Bioindicator of Soil Health. CAB International, Wallingford, UK.

Ilhamdi M. 2012. Insect diversity in soil on Endok Beach, West Lombok. MIPA Pijar J 7 (2): 55-59. DOI: 10.29303/jpm.v7i2.95 [Indonesian]

Jones DT, Eggleton P. 2000. Sampling termite assemblages in tropical forest: Testing a rapid biodiversity assemblage protocol. J Appl Ecol 37: 191-203.

Kanal A. 2004. Effects of fertilisation and edaphic properties on soilassociated Collembola in crop rotation. Agron Res 2 (2): 153-168.

Kinasih I, Cahyanto T, Ardian ZR. 2017. Perbedaan keanekaragaman dan komposisi dari serangga permukaan tanah pada beberapa zonasi di hutan Gunung Geulis. Sumedang. Jurnal ISTEK 10 (2): 19-32. [Indonesian]

Kovacs M. 1992. Biological indicators in environmental protection. Ellis Horwood Series in Environmental, Science and Technology, New York.

Kramadibrata I. 1995. Animal Ecology. ITB Perss, Bandung [Indonesia].

Krebs CJ. 1999. Ecological Methodology. $2^{\text {nd }}$ ed. Addition Wesley Longman, Inc., Menlo Park, California, USA.

Lachat T, Wermelingera B, Gossnerb MM, Busslerc H, Isacssond G, Müllerb J. 2012. Saproxylic beetles as indicator species for deadwood amount and temperature in European beech forests. Ecol Indic 23: 323-331.

Latumahina FS, Musyafa, Sumardi, Putra NS. 2014. Abundance and diversity of ants in the Sirimau conservation forest, Ambon. J Biospacies 7: 53-58. [Indonesian]

Lilies SC. 1992. Key Determination of Insects. Kanisius, Jakarta. [Indonesian]

Liu R, Zhu F, Song N, Yang Z, Chai Y. 2013. Seasonal distribution and diversity of ground arthropods in microhabitats following a shrub plantation age sequence in desertified steppe. PloS ONE 8(10): e77962. DOI: 10.1371/journal.pone.0077962.

Maftu'ah E, Arisoesiloningsih E, Handayanto E. 2002. Study of the potential diversity of macrofauna as a bioindicator of soil quality in several land uses. Biosciences 2: 34-47. [Indonesian]

Magurran AE. 1987. Ecological Diversity and Its Measurement. Chapman and Hill, London.

Nuraeni S, Mangesu N. 2017. Soil insect diversity in plantation forest and natural forest in the educational forest of Hasanuddin University. Satria J Nat Sci Series. XXXII Edition January 2017. [Indonesian]

Nasir M. 2013. Diversity of soil insects in the Sesaot Community forest work area of West Lombok, West Nusa Tenggara. J Biol Educ 2 (1): 31-40. [Indonesian]

Nieto A, Alexander KNA. 2010. European red list of saproxylic beetles. European Union Pr., Luxembourg.

Noerdjito WA. 2003. Diversity of beetles (Coleoptera). In: Amir M, Kahono S (eds) Insects of the West Java Mount Halimun National Park. Bogor (ID). JICA Biodiversity Conservation Project: 149-200. [Indonesian]

Notohadiprawiro T. 1999. Land and Environment. Directorate General of Higher Education Ministry of Education and Culture, Jakarta. [Indonesian]

Nurtjahya E, Setiadi D, Guhardja E, Muhadiono, Setiadi Y. 2007. Potensi Collembola sebagai indikator revegetasi tailing timah di Pulau 
Bangka. Jurnal Ilmu-ilmu Pertanian Indonesia 9: 113-123. [Indonesian]

Odum EP. 1998. The Basics of ecology. Third Edition. Gadjah Mada University Press, Yogyakarta. [Indonesian]

Ohsawa M. 2010. Beetle families as indicators of coleopteran diversity in forests: A study using malaise traps in the central mountainous region of Japan. J Insect Conserv 14 (5): 479-484.

Pearce JL, Venier LA. 2006. The use of ground beetles (Coleoptera: Carabidae) and spiders (Araneae) as bioindicators of sustainable forest management: A review. Ecol Indic 6: 780-793.

Permana SR. 2016. Diversity of soil insects in Manggis Gadungan nature reserve and Mangli Coffee plantation, Puncu District, Kediri Regency. http://etheses.uin-malang.ac.id/id/eprint/3160 [December 10, 2018]. [Indonesian]

Rohyani IS, Ahyadi H. 2017. Diversity and abundance of soil insects at Jeruk Manis protected forest in East Lombok (Indonesian) using several trapping methods. Biodiversitas 18 (2): 809-812.

Rohyani IS, Jaya INS, Haneda NF. 2013. Soil collembola abundance for time accomplishment estimation of revegetation from soil fertility aspect in the mining area of PT Newmont Nusa Tenggara. Forum Pascasarjana 36: 69-78. [Indonesian]

Rohyani IS. 2001. Soil Hexapoda diversity in various types of land cover in the mangrove ecosystem case study in West Nusa Tenggara Province. [Thesis]. Bogor Agricultural Institute, Bogor. [Indonesian].
Samways MJ, Bazelet C. 2011. Identifying grasshopper bioindicators for habitat quality assessment of ecological networks. Ecol Indicators 11 (5): 1259-1269

Schowalter TD. 2006. Insect ecology an ecosystem approach $2^{\text {nd }}$ edition. Elsevier inc, New York.

Shahabuddin. 2003. Utilization of insects as bioindicators of forest health. Introduction to the Philosophy of Science. Postgraduate of IPB, Bogor. [Indonesian]

Subahar TSS. 2000. The effect of land function change towards community structure of soil Arthropods: A case study at North Bandung. Symposium Proceedings on Biodiversity of Arthropods in Agricultural Production System. Entomology Community of Indonesia, Bogor, 16-18 October 2000. [Indonesian]

Suhardjono YR, Deharveng L, Bedos A. 2012. Biology-EcologyClassification of Collembola (Springtails). Vegamedia, Bogor. [Indonesian]

Suhardjono YR. 1985. The comparison of forest floor insects population at Wanariset Forest, Kalimantan Timur. Berita Biologi 3 (3): 104-107. [Indonesian]

Suin NM. 2006. Ecology of Soil Fauna. Bumi Aksara, Jakarta. [Indonesian] 